\title{
Pemberdayaan ekonomi kreatif berbasis kearifan lokal masyarakat dengan pendekatan outcome mapping
}

\author{
Sanuri Sanuri \\ Program Studi Pendidikan Luar Sekolah, Program Pascasarjana Universitas Negeri Yogyakarta \\ Jalan Colombo No. 1, Karangmalang, Yogyakarta 55281, Indonesia \\ * Corresponding Author. Email: sanuriamdali@gmail.com
}

Received: 13 May 2019; Revised: 20 October 2019; Accepted: 19 November 2020

\begin{abstract}
Abstrak: Penelitian ini bertujuan untuk mengetahui penerapan pendekatan outcome mapping pada proses pemberdayaan ekonomi kreatif berbasis kearifan lokal masyarakat di kampung Kais-Tapuri, Distrik Kais, Kabupaten Sorong selatan, Papua barat. Penelitian ini merupakan penelitian participatory action research dengan menggunakan pendekatan kualitatif dan kuantitatif. Subjek penelitian terdiri dari 20 perempuan usia produktif. Data penelitian diperoleh dengan teknik observasi, wawancara, dan dokumentasi. Hasil penelitian adalah sebagai berikut: (1) Perencanaan partisipatoris untuk identifikasi kebutuhan terkait ekonomi rumah tangga bersama dengan kepala kampung, aparat kampung, perwakilan perempuan di dua kampung (2) Penentuan mitra langsung dan stakeholder potensial, mitra langsung yang terpilih terdiri dari 20 perempuan usia produktif dari dua kampung, dan stakeholder potensial terdiri dari kepala kampung, pendeta, kepala suku, dan kader posyandu (3) Desain program yaitu berupa rancangan terarah yang terdiri dari: visi dan misi, mitra langsung, capaian dambaan, penanda kemajuan (4) Menentukan rencana kerja berupa pelatihan dan pendampingan (5) Indikator keberhasilan pelatihan adalah adanya perubahan perilaku mitra langsung yang dapat dilihat pada penanda kemajuan yang sudah dibuat selama semester pertama Kata Kunci: pemberdayaan, outcome mapping, ekonomi kreatif, kearifan lokal
\end{abstract}

\section{Creative economy empowerment based on community local wisdom with outcome mapping approach}

Abstract: This research aims to determine the application of the outcome mapping approach to the process of creating economic empowerment based on local wisdom in the Kais-Tapuri village, Kais District, South Sorong Regency, West Papua. This research is participatory action research with qualitative and quantitative approaches. The research subjects consisted of zo productive age women (housewives). The research data were obtained through observation, interview, and documentation techniques. The results of the research were as follows: (1) Participatory planning consisted of identifying needs related to household economics together with village heads, village officials, women representatives in two villages (2) Determination of Boundary partners and potential stakeholders, selected Boundary partners consisting of 20 women productive age of two villages, and potential stakeholders consist of village heads, pastors, chiefs, and Posyandu cadres (3) Program design is an intentional design consisting of vision and mission, boundary partners, Outcome challenges, progress marker (4) Determine work plans in the form of training and assistance (5) Indicators of successful training are changes in the behaviour of boundary partners that can be seen in the marker of progress made during the first semester

Keywords: empowerment, outcomes mapping, creative economy, local wisdom

How to Cite: Sanuri, S. (2020). Pemberdayaan ekonomi kreatif berbasis kearifan lokal masyarakat dengan pendekatan outcome mapping. JPPM (Jurnal Pendidikan dan Pemberdayaan Masyarakat), 7(2), 101-114. doi:https://doi.org/10.21831/jppm.v7i2.2487o

\section{PENDAHULUAN}

This is an open access article under the CC-BY-SA license. 


\section{JPPM (Jurnal Pendidikan dan Pemberdayaan Masyarakat), 7 (2), 2020 - 102}

Sanuri Sanuri

Perkembangan jaman yang semakin cepat mengakibatkan sebagian masyarakat tidak menikmati pembangunan dengan hasil yang memuaskan, ini terbukti dengan data yang dirilis oleh Badan Pusat Statistik, pada bulan maret 2017, jumlah penduduk miskin (penduduk dengan pengeluaran perkapita per-bulan dibawah garis kemiskinan) di Indonesia mencapai 27,77 juta orang $(10,64 \%)$, bertambah sebesar 6,90 ribu orang dibandingkan dengan kondisi september 2016, sebesar 27,76 juta orang. Berbanding lurus dengan meningkatnya jumlah penduduk miskin di Indonesia, Badan Pusat Statistik juga mencatat terdapat kenaikan jumlah angka pengangguran di Indonesia sebesar 10.000 orang menjadi 7,04 juta orang pada agustus 2017 dari agustus 2016 sebesar 7,03 juta orang.

Menurut Sumarto (2010:21) ada beberapa hal yang menyebabkan kondisi kemiskinan masih sulit untuk diminimalisir: pertama, kondisi anggota masyarakat yang belum ikut serta dalam proses yang berkualitas; kedua, rendahnya tingkat pendidikan masyarakat pedesaan; dan ketiga pembangunan yang direncanakan pemerintah tidak sesuai dengan kemampuan masyarakat untuk berpartisipasi, sehingga tidak dijangkau oleh masyarakat. Oleh karena itu harus dilakukan upaya-upaya terobosan baru oleh pemerintah maupun pihak terkait untuk secepatnya membantu masyarakat membangkitkan kesadaran dan potensi yang dimilikinya agar dapat bermanfaat bagi pembangunan bangsa.

Ekonomi kreatif menitikberatkan perhatiannya pada penciptaan barang dan jasa dengan mengandalkan keahlian, bakat, dan kreativitas sebagai kekayaan intelektual, merupakan bidang yang diharapkan mampu untuk mengatasi berbagai persoalan pengangguran maupun pengembangan usaha yang berdasarkan potensi ekonomi suatu daerah. Secara makro, ekonomi kreatif merupakan pilihan untuk mendukung pertumbuhan ekonomi, penciptaan lapangan kerja, maupun pengurangan penduduk miskin di Indonesia. Berbagai subsektor dalam industri kreatif berpotensi untuk dikembangkan, karena terdapat banyak sumber daya manusia kreatif dan kekayaan aneka budaya yang ada di Indonesia. Dari pemaparan mengenai ekonomi kreatif yang berkembang saat ini, terdapat korelasi positif antara ekonomi kreatif dalam upaya mengurangi angka pengangguran, ekonomi kreatif memberikan kesempatan untuk menciptakan lapangan pekerjaan.

Ekonomi kreatif bukan hanya diukur dari segi ekonomi tetapi juga dapat diukur dari segi dimensi budaya. Dewasa ini, ide-ide kreatif yang muncul pada dasarnya bersumber dari kearifan lokal daerah. Hal ini memberikan makna bahwa kearifan lokal sangat menentukan arah perkembangan ekonomi kreatif di Indonesia. Pengembangan ekonomi kreatif tidak terlepas dari budaya masyarakat setempat. Budaya masyarakat setempat merupakan kearifan lokal yang harus dilestarikan dan dikembangkan dalam bentuk terintegrasi dalam setiap kegiatan pembangunan. Kearifan lokal dalam budaya bisa dalam bentuk fisik dan non fisik. Kearifan lokal dalam bentuk fisik seperti kerajian, seni, kuliner sedangkan non fisik dapat berupa sesuatu yang memiliki nilainilai yang bermakna seperti budaya gotong royong, sikap bijak dalam pemanfaatan alam, dan lain-lain.

Observasi awal yang dilakukan peneliti terdapat perilaku masyarakat yang konsumtif, hal ini terlihat dari perilaku masyarakat yang banyak mendatangi kios ketika mendapatkan uang dari hasil bekerja, menjual sagu, ataupun uang dari hasil pembayaran adat, padahal masih ada beberapa bahan makanan yang bisa dikonsumsi di rumah. Perilaku konsumtif masyarakat didasari dari belum pahamnya kebutuhan dan keinginan, perilaku ini terlihat dari kebiasaan mereka dalam menghabiskan uang sekaligus, tanpa ada kebutuhan yang jelas, masih dalam keinginan semata. Hal ini menjadi dasar bahwa dalam upaya meningkatkan ekonomi masyarakat, perlu terlebih dahulu adanya proses penyadaran terkait dengan perilaku yang menghambat meningkatnya ekonomi masyarakat. untuk itu perlu dilakukan pemberdayaan dalam upaya penyadaran akan pemanfaatan kearifan lokal sebagai upaya peningkatan ekonomi kreatif masyarakat.

Memberdayakan perempuan berarti memberikan kesempatan kepada perempuan untuk berpartisipasi dalam berbagai hal yang bertujuan memberikan kekuatan bagi perempuan untuk memperbaiki perekonomian, meningkatkan kualitas kehidupan perempuan di mata masyara- 


\section{JPPM (Jurnal Pendidikan dan Pemberdayaan Masyarakat), 7 (2), 2020 - 103}

Sanuri Sanuri

kat, serta mengembangkan kemampuan yang dimiliki perempuan. Dalam pemberdayaan dibutuhkan prinsip sebagai dasar untuk berpikir, bertindak, serta melakukan hal lain sebagai acuan pembenaran. Tahapan pemberdayaan menurut Syamsi (2010, p.65) yakni dimulai dari bagaimana masyarakat dapat mengembangkan pemikiran mereka dalam berbagai hal untuk meningkatkan kehidupan mereka. Kemauan untuk mengembangkan diri mereka yang ditunjang dengan keahlian untuk merealisasikan keterampilan yang dimiliki serta pengalaman sehingga mereka merasa percaya diri untuk terus berkembang. Kemampuan serta rasa percaya diri menjadikan masyarakat yang mendapatkan pemberdayaan menjadi mandiri dan terus berusaha untuk meningkatkan kesejahteraan hidup. Melalui aktifitas pendidikan nonformal diharapkan dapat membantu masyarakat berdaya sesuai dengan kebutuhan masyarakat itu sendiri

Peran perempuan, terutama ibu rumah tangga sangat dibutuhkan dalam mengatur ekonomi rumah tangga. Perempuan di Papua, khususnya di Kampung Kais dan Tapuri memiliki tugas dan tanggung jawab tidak hanya menyiapkan makanan dengan masak di dapur, tetapi juga melakukan pekerjaan seperti laki-laki. Dimulai dari ikut bersama suami menebang sagu, kemudian dilanjutkan menokok sagu, dilanjutkan pula meremas sagu, dan melakukan pengolahan menjadi bahan makanan yang dikonsumsi. Untuk itulah perlu dilakukan pemberdayaan mamamama di Kampung Kais dan Tapuri dengan pendekatan outcome mapping, dimana melihat perubahan perilaku mama-mama dalam mengatur ekonomi rumah tangga, sehingga diharapkan dapat meningkatkan ekonomi keluarga dan masyarakat pada umumnya dengan memanfaatkan potensi alam dan kearifan lokal masyarakat.

\section{METODE}

Penelitian ini merupakan participatory action research (PAR) dengan pendekatan kualitatif dan kuantitatif. Penelitian ini merujuk pada konsep dari Stephen Kemmis \& Robin Mc Taggart yaitu Model Participatory Action Research (PAR) yang mengacu pada model penelitian tindakan (Denzin \& Lincoln, 2009, p. 470) yang terdiri dari 4 aspek, yakni perencanaan (planning), tindakan (acting), pengamatan (observing), dan refleksi (reflecting). Penelitian ini dilaksanakan di Kampung Kais dan Tapuri, Distrik Kais, Kabupaten Sorong Selatan, Papua Barat pada maret 2017 sampai Februari 2018. Subjek dalam penelitian ini adalah 20 perempuan usia produktif dari dua kampung yaitu Kais dan Tapuri. Teknik analisis data yang dilakukan menggunakan data kualitatif dan data kuantitatif. Data kualitatif didapat dari hasil observasi, wawancara, dan dokumentasi. Selanjutnya dianalisis dengan teknik deskriptif. Sedangkan data kuantitatif didapat dari hasil proses pemberdayaan berupa perubahan perilaku mitra langsung. Data kuantitatif diambil dari hasil observasi saat proses pelatihan ataupun pendampingan. Selanjutnya data dianalisis dengan teknik statistik deskriptif berupa penyajian data melalui tabel dan diagram.

\section{HASIL DAN PEMBAHASAN}

\section{Analisa Kondisi Kampung Terkait Ekonomi}

Pada proses penggalian informasi kepada warga dan tokoh kampung, maka didapatkan permasalahan-permasalahan terkait ekonomi yang ada di kampung Kais-Tapuri sebagai berikut. (a) budaya konsumtif masyarakat (b) belum bisa menyimpan uang (c) belum memahami kebutuhan dan keinginan (d) belum mempunyai usaha mandiri sebagai penghasilan tambahan (e) Belum mampu mengolah hasil alam secara optimal. Berdasarkan data tersebut, maka dimunculkan program yang menjadi pilihan dan kebutuhan warga yakni pemberdayaan ekonomi kreatif berbasis kearifan lokal melalui pelatihan dan pendampingan pada kelompok perempuan usia produktif.

Memberdayakan perempuan memberikan kesempatan kepada perempuan untuk berpartisipasi dalam berbagai hal yang bertujuan memberikan kekuatan bagi perempuan untuk memperbaiki perekonomian, meningkatkan kualitas kehidupan perempuan di mata masyara- 
kat, serta mengembangkan kemampuan yang dimiliki perempuan. Dalam pemberdayaan dibutuhkan prinsip sebagai dasar untuk berpikir, bertindak, serta melakukan hal lain sebagai acuan pembenaran. Menurut Anwas (2014, pp. 58-60) terdapat prinsip-prinsip yang harus dilakukan dalam proses pemberdayaan perempuan sehingga dapat tercapai sesuai dengan tujuan yang diinginkan. Prinsip-prinsip tersebut yaitu: (1) Pemberdayaan dilakukan dengan cara yang demokratis dan menghindari unsur paksaan. Setiap individu memiliki hak yang sama untuk berdaya. Setiap individu juga memiliki kebutuhan, masalah, bakat, minat, dan potensi yang berbeda. Unsur-unsur pemaksaan melalui berbagai cara perlu dihindari karena bukan menunjukkan ciri dari pemberdayaan (2) Kegiatan pemberdayaan didasarkan pada kebutuhan, masalah, potensi klien atau sasaran. Hakikatnya setiap manusia memiliki kebutuhan, dan potensi dalam dirinya. Proses pemberdayaan dimulai dengan menumbuhkan kesadaran kepada sasaran akan potensi dan kebutuhannya yang dapat dikembangkan dan diberdayakan untuk mandiri. Proses pemberdayaan juga dituntut berorientasi kepada kebutuhan dan potensi yang dimiliki sasaran (3) Sasaran pemberdayaan adalah sebagi subyek atau pelaku dalam kegiatan pemberdayaan. Oleh karena itu sasaran menjadi dasar pertimbangan dalam menentukan tujuan, pendekatan, dan bentuk aktivitas pemberdayaan (4) Pemberdayaan berarti menumbuhkan kembali nilai, budaya, dan kearifan-kearifan lokal yang memiliki nilai luhur dalam masyarakat. Budaya dan kearifan lokal seperti sifat gotong royong, kerjasama, hormat kepada yang lebih tua, dan kearifan lokal lainnya sebagai jati diri masyarakat perlu ditumbuhkembangkan melalui berbagai bentuk pemberdayaan sebagai modal sosial dalam pembangunan (5) Pemberdayaan merupakan sebuah proses yang memerlukan waktu, sehingga dilakukan secara bertahap dan berkesinambungan. Tahapan ini dilakukan secara logis dari yang sifatnya sederhana menuju yang kompleks (6) Kegiatan pendampingan atau pembinaan perlu dilakukan secara bijaksana, bertahap, dan berkesinambungan. Kesabaran dan kehati-hatian pemberdaya perlu dilakukan terutama dalam menghadapi keragaman karakter, kebiasaan, dan budaya masyarakat yang sudah lama tertanam (7) Pemberdayaan tidak bisa dilakukan satu aspek saja, tetapi perlu dilakukan secara holistic terhadap semua aspek kehidupan yang ada dalam masyarakat (8) Pemberdayaan perlu dilakukan terhadap kaum perempuan terutama remaja dan ibu-ibu muda sebagai potensi dasar dalam mendongkrak kualitas kehidupan keluarga dan pengentasan kemiskinan (9) Pemberdayaan dilakukan agar masyarakat memiliki kebiasaan untuk belajar, beljaar sepanjang hayat (lifelong learning/education). Individu dalam masyarakat perlu dibiasakan belajar menggunakan berbagai sumber yang tersedia. Sumber belajar tersebut bisa: pesan, alat, teknik, dan juga lingkungan sekitar tempat mereka tinggal.

\section{Kearifan Lokal Masyarakat Kais-Tapuri}

Kampung Kais dan Tapuri merupakan kampung yang terletak di daerah aliran sungai Kais, yang merupakan wilayah kabupaten Sorong Selatan, provinsi Papua barat. Jumlah penduduk di kedua kampung berjumlah 802 jiwa, dimana Kampung Kais memiliki 512 jiwa yang terdiri dari 242 laki-laki dan 270 perempuan. Kampung Tapuri memiliki 290 jiwa yang terdiri dari 151 jiwa dan 139 perempuan. Komposisi laki-laki dan perempuan di kedua kampung memiliki komposisi yang hampir sama. Penduduk laki-laki lebih mendominasi di Kampung Tapuri sedangkan penduduk perempuan lebih banyak berada di Kampung Kais (Data primer, 2017).

Usia penduduk di Kampung Kais dan Tapuri banyak didominasi oleh penduduk usia produktif (15-64 tahun). Penduduk usia produktif di Kampung Kais sebesar 227 jiwa dan 237 jiwa di Tapuri. Penduduk dengan usia belum produktif (o-15 tahun) berjumlah 147 jiwa di Kais dan 111 di Tapuri. Penduduk usia tidak produktif ( $>64$ tahun) berjumlah 6 jiwa di Kais dan 8 jiwa di Tapuri. Hal tersebut menunjukkan bahwa penduduk usia produktif lebih banyak dibandingkan penduduk usia non-produktif. Secara keseluruhan juga menunukkan bahwa penduduk usia muda masih mendominasi di kedua kampung dan golongan tua semakin sedikit.

Pendidikan di Kampung Kais dan Tapuri masih tergolong rendah dimana masyarakat masih didominasi oleh pendidikan rendah setingkat SD, yaitu sebesar $44.4 \%$ di Kais dan $42.3 \%$ di Tapuri. Hal ini menunjukkan bahwa hampir setengah penduduk di kedua kampung memiliki 


\section{JPPM (Jurnal Pendidikan dan Pemberdayaan Masyarakat), 7 (2), 2020 - 105}

Sanuri Sanuri

pendidikan yang rendah. Pendidikan terakhir tersebut juga banyak didominasi oleh golongan usia muda dan tua yang tidak melanjutkan pendidikan SMP dikarenakan tidak lolos dalam ujian masuk SMP. Pendidikan menengah relatif banyak dimana yang sedang menempuh atau telah menempuh pendidikan berjumlah $17 \%$ di Kais dan $20.8 \%$ di Tapuri. Sedangkan pendidikan SMA di Kais sebesar $11.1 \%$ dan 12.3\%. Angka tersebut cukup menunjukkan bahwa masih banyak beberapa penduduk yang mampu melanjutkan pendidikan setelah Sekolah Dasar, Hal ini juga ditunjang dengan adanya infrastruktur berupa SMP dan SMK di Kampung Tapuri. Namun tingginya tingkat pendidikan masih belum dapat mengukur pengetahuan para pelajar, dimana masih banyak ditemukan pelajar setingkat SMP dan SMA/SMK yang belum fasih dalam membaca dan menulis.

Penduduk di kedua kampung dapat dibedakan menjadi 3 mayoritas status pekerjaan yaitu golongan tidak bekerja, pelajar/mahasiswa dan pekerja keluarga. Pekerjaan di Kampung Kais dan Tapuri masih didominasi oleh pelajar/mahasiswa yaitu sebesar di 34.9\% Kais dan 38.3\% di Tapuri. Persentase penduduk dengan pekerjaan sebagai penokok sagu sebagai mata pencaharian utama yaitu sebesar $19 \%$ di Kais dan $24 \%$ di Tapuri. Hasil enumerasi yang menunjukkan banyaknya penduduk yang tidak bekerja kurang akurat karena pada dasarnya sebagian besar dari mereka juga turut serta dalam membantu keluarga untuk kegiatan menokok sagu. Pekerjaan lainnya ada status pekerjaan berusaha sendiri yang terdiri dari pengusaha kios dan pekerjaan buruh/karyawan/pegawai yang banyak bekerja sebagai karyawan perusahaan kelapa sawit, PERHUTANI, dan pegawai distrik.

Pekerjaan di kedua kampung banyak berkecimpung di sektor pertanian, perikanan, kehutanan, dan peternakan dimana mendominasi sebesar $76.3 \%$ di Kais dan 80.7\% di Tapuri. Pekerjaan penduduk banyak tergantung dari hasil hutan utama yaitu sagu. Sagu menjadi mata pencaharian utama mereka sehari-hari. Pekerjaan dari sektor ini banyak mengalami ketidaktentuan dari segi pendapatan sehari-hari dari ketidakpastian hasil tokok sagu dan hasil yang mereka jual. Sektor pekerjaan lain adalah jasa kemasyarakatan, sosial dan perorangan sejumlah 15.8\% di Kais dan 13.2\% di Tapuri. Sektor ini banyak didominasi oleh penduduk yang bekerja sebagai PNS di pemerintahan di Temiabuan maupun sebagai pegawai Distrik Kais.

Masyarakat Kais dan Tapuri sepenuhnya bergantung kepada hasil sagu. Mayoritas masyarakat kedua kampung sehari-hari memanfaatkan sagu sebagai makanan pokok seharihari. Hasil menunjukkan bahwa masyarakat Kais dan Tapuri mengkonsumsi sagu sebesar $84 \%$ dari jumlah penduduk dan $16 \%$ yang mengkonsumsi sagu sebagai makanan pokok. Hal tersebut menunjukkan bahwa masih banyaknya masyarakat lokal yang mengkonsumsi sagu dibandingkan beras. Masyarakat yang mengkonsumsi beras umumnya bukan berasal dari Kais dan Tapuri (pendatang).

Pemanfaatan hasil kebun yang diterapkan masyarakat Kais dan Tapuri cenderung dikonsumsi sendiri, yaitu sebesar 74\%. Hasil kebun yang dijual hanya sebesar 19\%. Hasil tersebut menunjukkan bahwa masyarakat cenderung mengkonsumsi sendiri namun ada beberapa persentase yang hasilnya dijual dikarenakan hasil yang berlebih sehingga dapat diperjuabelikan. Pemanfaatan hasil kebun yang dikonsumsi yaitu sayur-sayuran seperti cabai, bayam, terong, dan lainnya serta hasil kebun seperti keladi, pisang, umbi-umbian lainnya. Hampir seluruh kepala keluarga di Kais dan Tapuri menokok sagu, yaitu sebesar 98\% dan sisanya tidak menokok sagu yaitu sebesar $2 \%$. Mayoritas kepala keluarga hampir ada salah satu anggota keluarga yang melakukan kegiatan tokok sagu. Kegiatan menokok sagu dalam keluarga dapat karena untuk konsumsi keluarga atau untuk dijual. Lokasi menokok sagu yang paling banyak dilakukan berada di dusun. Kepala keluarga yang menokok sagu di dusun sebesar $61 \%$. Sedangkan pinggir sungai sebesar $33 \%$ dan yang di pekarangan hanya $6 \%$. Lokasi dusun yang banyak terdapat sagu alami biasanya banyak dimanfaatkan warga selain menokok sagu. Lokasi dusun biasanya dijadikan juga sebagai "kebun apatar/ulat sagu" yang dikonsumsi juga sebagai lauk. Sedangkan ada yang menokok di pinggir sungai dikarenakan dekat dengan sumber air dan dekat untuk dilakukan untuk dialirkan melalui sungai. 


\section{JPPM (Jurnal Pendidikan dan Pemberdayaan Masyarakat), 7 (2), 2020 - 106}

Sanuri Sanuri

\section{Model Pemberdayaan Masyarakat dengan Pendekatan Outcome Mapping}

Penelitian yang dilakukan adalah menggunakan pendekatan outcome mapping, dimana fokus pada perubahan perilaku masyarakat baik individu maupun kelompok (komunitas). Outcome mapping dikembangkan untuk mengatasi permasalahan mendasar terkait dengan pelaporan tentang dampak pembangunan. Kompleksitas dan fleksibelnya proses-proses pembangunan mempunyai arti bahwa pencapaian "dampak" memerlukan keterlibatan berargam aktor, dan seringkali berlangsung dalam jangka waktu yang cukup panjang.

Beberapa tahun terakhir ini outcome mapping semakin mendapat perhatian dari praktisi pembangunan di dunia, sebagai sebuah pendekatan alternatif untuk perencanaan, pemantauan dan evaluasi program pembangunan. Di Indonesia outcome mapping juga mulai mendapat perhatian di kalangan praktisi pembangunan, outcome mapping di Indonesia telah diterapkan oleh dua organisasi, yaitu VECO Indonesia dan ACCESS Tahap II.

Tahun 2017, peneliti bergabung dengan Yayasan Indonesia Lebih Baik (YILB) dalam melakukan pemberdayaan masyarakat di wilayah Kabupaten Sorong selatan, Papua Barat. Dalam melakukan pemberdayaan YILB menggunakan pendekatan outcome mapping dalam panduan perencanaan, pemantauan dan evaluasi program untuk membangun masyarakat Sorong selatan mandiri. Yayasan Indonesia Lebih Baik (YILB) melakukan pemberdayaan di 10 kampung yang terdampak perusahaan sawit milik ANJ Group, namun penelitian hanya dilakukan di dua kampung, dimana peneliti melakukan pendampingan.

Terry Smutylo dalam jurnal Outcome mapping: A method for tracking behavioural changes in development programs mendefinisikan bahwa "Outcome mapping is a methodology for planning, monitoring and evaluating development initiatives that aim to bring about social change"

Dari definisi tersebut dapat diuraikan bahwa: (1) Outcome mapping menggunakan metode partisipatif dalam planning, monitoring dan evaluation (2) Outcome mapping berfokus terhadap perubahan perilaku mitra langsung (kelompok sasaran) dimana program tersebut bekerja (3) Outcome mapping berorientasi pada pembelajaran sosial dan organisasi. Definisi lain yang dikemukakan oleh Deprez, et al (2010) dalam buku outcome mapping mendefinisikan bahwa:

"Outcome mapping (OM) adalah kerangka pikir dalam manajemen program. OM mengakui kompleksitas sistem sosial dan keterbatasan pengaruh intervensi program. Pendekatan ini berorientasi pada perubahan perilaku aktor, interaksi antaraktor, dan pemetaan perubahan tersebut. Didalamnya ada proses merencanakan: siapa berperan apa serta hubungan satu sama lain; bagaimana cara mencapainya; dan bagaimana kita tahu kemajuannya"

Outcome mapping adalah suatu pendekataan perencanaan, pemantauan dan evaluasi yang terpadu dan digunakan saat awal program setelah fokus utama program ditentukan. Hal ini berarti bahwa program perlu menetapkan arah strategis atau isu utama terlebih dahulu sebelum mengembangkan sebuah kerangka outcome mapping. Outcome mapping membantu program menjelaskan apa yang ingin dicapai, dengan siapa, dan bagaimana. Kemudian menawarkan sebuah metode untuk memantau perubahan-perubahan pada mitra langsung (kelompok sasaran) dan perubahan di dalam program sebagai sebuah organisasi.

Terdapat beberapa istilah yang digunakan dalam pendekatan outcome mapping, diantaranya sebagai berikut: (1) Mitra Langsung: Individu, kelompok atau organisasi yang berinteraksi dengan program secara langsung dan yang ingin dipengaruhi oleh program (2) Capaian dambaan: Deskripsi perubahan ideal yang ingin dipengaruhi oleh program dalam perilaku, hubungan, kegiatan, dan/atau tindakan mitra perbatasan (3) Penanda kemajuan: Seperangkat indikator perubahan perilaku mitra langsung yang berfokus pada kedalaman atau kualitas perubahan.

Pelaksanaan pendekatan outcome mapping dibagi menjadi tiga tahap. Tahap pertama adalah rancangan terarah (intentional design) yang membantu program membangun kesepakatan bersama tentang perubahan tingkat makro yang ingin diwujudkan serta merencanakan strategi yang akan digunakan. Tahap ini membantu menjawab empat pertanyaan: mengapa? 
(apa visi dan misi program?), siapa? (siapa mitra langsung program?), apa? (apa saja perubahan yang dicari?) dan bagaimana? (bagaimana program akan berkontribusi pada proses perubahan itu?)

Tahap kedua adalah monitoring capaian dan kinerja program. Tahapan ini memberikan kerangka untuk memantau kegiatan yang sedang berlangsung dan bagaimana kemajuan mitra langsung terhadap pencapain hasil. Proses ini sebagian besar didasari penilaian diri secara sistematis. Tahap ini meliputi penyediaan alat-alat atau perangkat pengumpulan data untuk berbagai elemen yang diidentifikasi dalam tahap rancangan terarah: jurnal capaian (penanda kemajuan), jurnal strategi (peta strategi), dan jurnal kinerja (perilaku berorganisasi).

Tahap ketiga adalah perencanaan evaluasi. Tahap ini membantu program untuk mengidentifikasi prioritas evaluasi dan mengembangkan rencana evaluasi. Proses ketiga tahapan tersebut dapat digambarkan dalam bagan berikut:

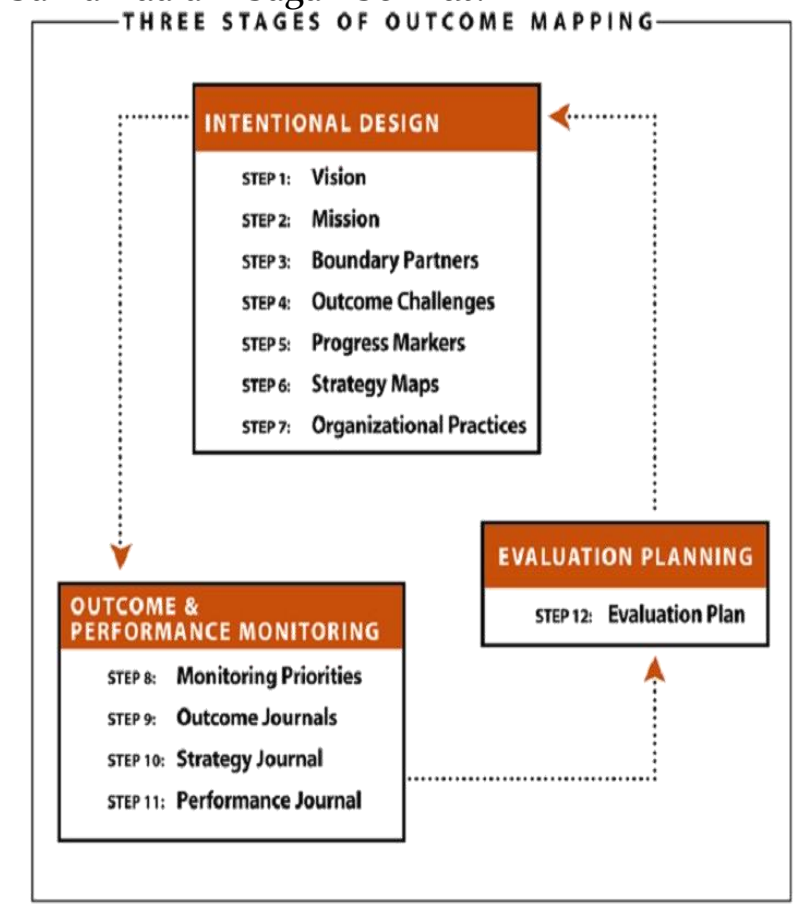

Gambar 1. Tahapan outcome mapping (Deprez, et al (2010)

\section{Assesment Terkait Identifikasi Kebutuhan Ekonomi Rumah Tangga}

Peneliti mengawali penelitian melalui pendekatan outcome mapping dengan tahapan assesment. Dalam menyusun pertanyaan tentang konsep ekonomi masyarakat, peneliti merumuskan pertanyaan yang mendukung untuk mendapatkan informasi terkait konsep uang, konsep belanja, konsep menabung, konsep kasbon, dan tentang pendapatan masyarakat. Untuk mendapatkan jawaban dari pertanyaan tentang konsep ekonomi rumah tangga, peneliti melakukan observasi dan tanya jawab langsung bersama masyarakat baik melalui aktivitas sehari-hari dan forum diskusi masyarakat.

Hasil assesment tentang konsep uang bagi masyarakat dapat digambarkan bahwa sebelum adanya pedagang yang masuk ke kampung Kais dan tapuri, masyarakat melakukan transaksi untuk memenuhi kebutuhan sehari-hari (pangan, sandang dan papan) dengan cara barter atau menukar barang hasil dari "mencari" di alam, seperti sagu, hasil kebun (pisang, singkong, sayur, dll), hasil buruan (daging babi, rusa,burung), hasil pencarian (ikan, udang, kerang). Setelah pendatang masuk, baik dari perusahaan kayu ataupun pedagang dari luar kampung datang, masyarakat mulai mengenal uang. Saat ini uang merupakan bernilai penting bagi masyarakat, dalam kesehariannya masyarakat menggunakan uang untuk memenuhi kebutuhan makan, rumah, pakaian, biaya pendidikan, pembayaran adat, transportasi. Untuk itulah masyarakat mulai bekerja untuk mendapatkan uang yang digunakan untuk kebutuhan sehari-hari. Mata pencaharian masyarakat Kais dan Tapuri mayoritas bekerja di sektor pertanian, perikanan dan 
kehutanan. Pekerjaan penduduk banyak tergantung dari hasil hutan utama yaitu sagu. Sagu menjadi mata pencaharian utama mereka sehari-hari. Pekerjaan dari sektor ini banyak mengalami ketidaktentuan dari segi pendapatan sehari-hari, sehingga masyarakat tidak mempunyai pendapatan tetap untuk memenuhi kebutuhan sehari-hari.

Hasil assesment tentang konsep belanja bagi masyarakat dapat digambarkan bahwa masyarakat mulai melakukan transaksi jual beli sejak adanya pedagang/kios yang masuk ke kampung. Sebelum adanya pedagang, masyarakat memenuhi kebutuhannya dengan 'mencari' dari alam, bahkan gula dan garam dibuat dari bahan alam oleh masyarakat sendiri. Setelah adanya kehadiran pendatang dimana masyarakat diperkenalkan dengan barang-barang instan, sistem tukar, dan uang, masyarakat mulai memenuhi kebutuhan dengan cara lain, yaitu membeli di kios/jolor, ataupun membeli di sesama masyarakat. Dalam melakukan proses transaksi jual beli (belanja), adanya perilaku konsumtif masyarakat, terlihat dari perilaku menghabiskan uang sekaligus, uang yang dibawa saat membeli di kios langsung dibelanjakan semua jika masih ada sisa, banyaknya masyarakat yang membeli di kios pada saat mendapatkan uang dari hasil bekerja di perusahaan di kawasan sekitar kampung, jual sagu, pembayaran adat dan proyek kampung. Konsumsi gula, kopi, garam, rokok, minyak goreng menjadi kebutuhan primer bagi masyarakat.

Hasil assesment tentang konsep menabung bagi masyarakat dapat digambarkan bahwa masyarakat baru memahami bahwa menabung adalah menyimpan dalam bentuk uang (di rumah, di bank). Masyarakat belum memahami akan pentingnya menabung untuk kebutuhan sehari-hari seperti pangan, papan, dan sandang serta pendidikan, sehingga bukan menjadi prioritas masyarakat. Untuk itulah masyarakat masih sering menggunakan kasbon untuk memenuhi kebutuhan sehari-hari, karena tidak mempunyai simpanan masa depan. Kasbon adalah pembelian barang di kios untuk memenuhi kebutuhan, tetapi tidak dibayar langung (hutang). Pelunasan hutang terkadang tidak dilakukan tepat waktu atau saat masyarakat sudah memiliki uang. Terkadang saat sudah melunasi kasbon, bersamaan dengan itu masyarakat melakukan kasbon lagi.

Hasil assesment tentang pendapatan masyarakat Kais dan Tapuri dapat digambarkan bahwa kebanyakan masyarakat memiliki pendapatan yang tidak tetap/tidak menentu, karena kebanyakan masyarakat tidak memiliki pekerjaan tetap. Jika dibandingkan dengan pengeluaran masyarakat, tidak sebanding dengan pendapatan masyarakat, sehingga banyak masyarakat yang menggunakan sistem kasbon dalam konsep belanja. Untuk itulah perlu adanya pendidikan akan pentingnya manajemen keuangan, agar dapat mengelola pendapatan dari hasi menjual sagu, ikan, sayur atau bekerja sebagai karyawan di perusahaan.

Hasil assesment awal yang dilakukan peneliti dapat menganalisis masalah yang terjadi di masyarakat terkait ekonomi rumah tangga, yaitu adanya budaya konsumtif masyarakat, yang disebabkan belum mempunyai pemahaman akan kebutuhan dan keinginan, belum memahami konsep menabung (menyimpan uang), belum mempunyai penghasilan tetap untuk memenuhi kebutuhan sehari-hari, belum mampu mengolah potensi alam menjadi ekonomi kreatif. Dari permasalahan tersebut sehingga perlu adanya proses pemberdayaan dalam bentuk pendidikan nonformal dan pendampingan ekonomi kreatif berbasis kearifan lokal dan potensi sagu masyarakat, sehingga masyarakat mempunyai penghasilan tambahan dari usaha mandiri ataupun kelompok.

\section{Penentuan Mitra Langsung dan Stakeholder Potensial}

Boundary partners: Individuals, groups or organizations with which the program interacts directly and which the program hopes to influence (Terry Smutylo). Dari definisi Terry Smutylo dapat disimpulkan bahwa mitra langsung adalah individu atau kelompok dimana menjadi sasaran langsung dari program yang kita jalankan dan yang ingin dipengaruhi. Mitra langsung ini yang akan dilihat perubahan perilakunya, sehingga diharapkan dapat memberikan pengaruh

kepada orang lain disekitarnya (penerima manfaat). Dalam memilih mitra langsung, peneliti melihat dari faktor-faktor yaitu: individu yang berpengaruh di kampung, individu yang memiliki 
kepemimpinan yang baik di kampung (dapat memimpin orang lain), individu yang memiliki kekuasaan (jabatan) di kampung, individu yang memiliki potensi di bidang program yang akan kita jalankan, individu yang semangat untuk belajar dan mengembangkan kreativitas dalam pembelajaran. Setelah melakukan observasi dari 157 KK di Kais dan 94 KK di Tapuri, tidak semua masyarakat tinggal di kampung, ada yang tinggal di Dusun (hutan), di ibukota Kabupaten, Teminabuan, sehingga hanya sekitar 50 mama-mama yang tinggal di kampung. Untuk itu peneliti menetapkan nama-nama Mitra langsung seperti terlihat pada Tabel 1.

Tabel 1. Nama Mitra Langsung Program

\begin{tabular}{clclc}
\hline No. & Nama Mitra Langsung & $\begin{array}{c}\text { Pendidikan } \\
\text { Terakhir }\end{array}$ & \multicolumn{1}{c}{ Jabatan di Kampung } & $\begin{array}{c}\text { Asal } \\
\text { kampung }\end{array}$ \\
\hline 1. & Debora Tebe & SMP & kader Posyandu & Tapuri \\
2. & Sipora Abago & SD & Mama kampung & Kais \\
3. & Susana Batong & SMP & kader Posyandu, ketua dana respek Tapuri & Tapuri \\
4. & Sopia Kabere & SD & Kelompok tani & Tapuri \\
5. & Yuliana Kimko & SD & Kelompok tani & Tapuri \\
6. & Selina Koire & SMP & Anggota PAM & Kais \\
7. & Dorkas Lehalima & SD & Kader Posyandu, guru PAUD Sion Kids, & Kais \\
& & & pengasuh sekolah Minggu & \\
8. & Tidora Tebe & SD & Kelompok tani & Kais \\
9. & Alfonsina Nipay & SD & ketua kelompok tani, kerajinan kain rumput & Tapuri \\
10. & Yosina Monsafe & SD & kelompok tani & Tapuri \\
11. & Selina Ginuni & SD & Kelompok tani, kerajian kain rumput & Tapuri \\
12. & Dorsila Saimar & SD & kader Posyandu & Kais \\
13. & Yakoba Bitoke & SD & Kelompok kumpul sagu & Kais \\
14. & Sherlin Batong & SMP & pengasuh sekolah minggu & Tapuri \\
15. & Kalorina Bandi & SD & kelompok tani & Kais \\
16. & Ottovina Abago & SD & kelompok tani & Tapuri \\
17. & Yokbet Sira & SD & kelompok tani & Tapuri \\
18. & Amelia Rariaro & SD & kader posyandu & Kais \\
19. & Agustina Asikasau & SD & kelompok tani & Kais \\
20. & Dorthea Saimar & SD & Kerajinan kain rumput & Kais \\
\hline
\end{tabular}

Sementara itu, stakeholder potensial adalah individu yang memiliki potensi untuk mendukung berjalannya program, misalnya kepala kampung, kepala suku, aparat kampung, majelis gereja, ketua majelis. Peran stakeholder potensial sangat dibutuhkan, misalnya ketika akan mengadakan program, maka perlu koordinasi dengan kepala kampung untuk mengumpulkan mama-mama dna menyediakan tempat.

\section{Merancang progam (Desain Program)}

Rancangan program dalam pendekatan outcome mapping menggunakan Rancangan Terarah (RT) yang disusun dari outcomes perubahan perilaku yang diharapkan terjadi pada Mitra Langsung (Tabel 2). Dalam menyusun rancangan terarah, peneliti merujuk data pada assesment yang dilakukan di awal penelitian. Berikut Rancangan terarah pada bidang ekonomi rumah tangga.

\section{Penerapan Model Pemberdayaan (Implementasi)}

Dalam menerapkan model pemberdayaan, peneliti menggunakan pendekatan outcome mapping. Peneliti melakukan proses pemberdayaan dalam dua tahap, yaitu pelatihan ekonomi rumah tangga dan pendampingan. Model pemberdayaan peneliti dibuat dalam bentuk rencana kerja (workplan) yang dilakukan tiap bulan (Tabel 3). Berikut rencana kerja yang dibuat peneliti untuk mencapai Rancangan terarah program pemberdayaan dalam meningkatkan ekonomi kreatif mama-mama di kampung Kais dan Tapuri: 
JPPM (Jurnal Pendidikan dan Pemberdayaan Masyarakat), 7 (2), 2020 - 110

Sanuri Sanuri

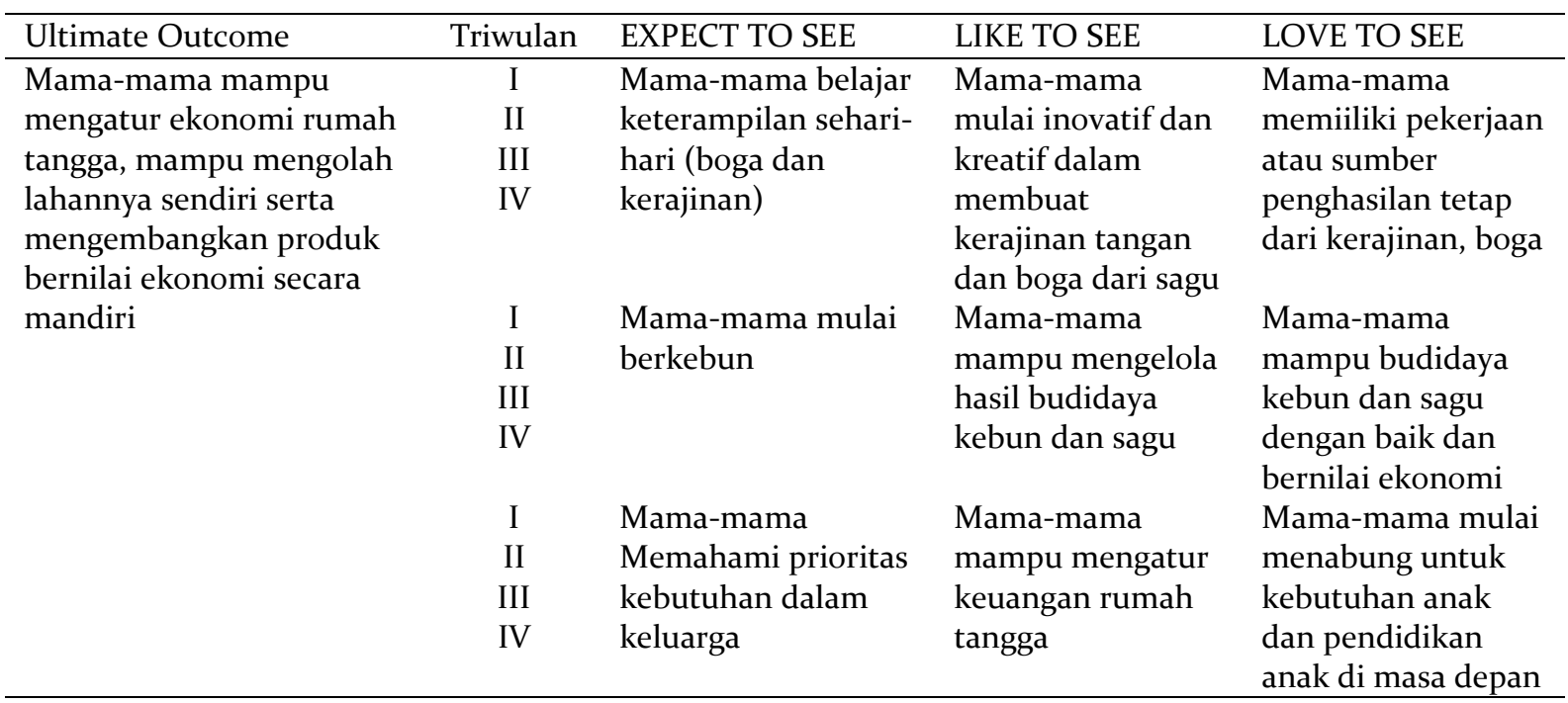

Tabel 3. Rencana Kerja Program

\begin{tabular}{|c|c|c|c|}
\hline $\begin{array}{l}\text { Rencana } \\
\text { Kegiatan di } \\
\text { Masyarakat } \\
\end{array}$ & Keterangan & Outcome & Realisasi Frekuensi Pelaksanaan \\
\hline \multirow[t]{2}{*}{$\begin{array}{l}\text { Pelatihan } \\
\text { tentang } \\
\text { pengelolaan } \\
\text { budidaya kebun } \\
\text { dan transaksi } \\
\text { jual beli } \\
\text { hasilnya }\end{array}$} & $\begin{array}{l}\text { Penguatan } \\
\text { kapasitas } \\
\text { bidang } \\
\text { pengelolaan } \\
\text { ekonomi } \\
\text { keluarga }\end{array}$ & $\begin{array}{l}\text { Mama dapat mengelola } \\
\text { keuangan keluarga dan hasil } \\
\text { kebun (Termasuk di dalamnya } \\
\text { pengelolaan potensi lokal sagu) } \\
\text { dan muncul perilaku } \\
\text { menyimpan/menabung }\end{array}$ & $\begin{array}{l}\text { untuk proses pertemuan mama- } \\
\text { mama (pelatihan) dilakukan } 1 \\
\text { bulan sekali, namun dilakukan } \\
\text { proses pendampingan setiap hari } \\
\text { dengan berkunjung ke rumah- } \\
\text { rumah mitra langsung ataupun } \\
\text { langsung dalam kelompok } \\
\text { kerajinan tangan dan boga. Materi } \\
\text { pelatihan dalam tiap bulan } \\
\text { berganti tema (berkembang), } \\
\text { sebagai berikut: (1) Kebutuhan dan } \\
\text { keinginan; (2) Pencatatan } \\
\text { pendapatan dan pengeluaran; (3) } \\
\text { manajemen keuangan keluarga; } \\
\text { (4) pentingnya menabung; (5) } \\
\text { Usaha mandiri }\end{array}$ \\
\hline & $\begin{array}{l}\text { Penguatan } \\
\text { kapasitas } \\
\text { bidang } \\
\text { pertanian }\end{array}$ & $\begin{array}{l}\text { Mama-mama memiliki kebun } \\
\text { tak jauh dari rumah dengan } \\
\text { tanaman variatif dan bisa } \\
\text { berkebun dengan baik }\end{array}$ & $\begin{array}{l}\text { Penguatan kapasitas bidang } \\
\text { pertanian dilakukan } 1 \text { kali dalam } \\
\text { setahun (hanya sebagai materi } \\
\text { penunjang) dimana peneliti } \\
\text { bekerja sama dengan lembaga lain } \\
\text { dalam bidang pertanian organik, } \\
\text { namun praktek dan } \\
\text { pendampingan dilakukan secara } \\
\text { rutin oleh peneliti dari mulai } \\
\text { pembersihan lahan kebun, } \\
\text { pengolahan lahan, penanaman } \\
\text { sayur, pembuatan pupuk dan } \\
\text { pestisida organik, sampai } \\
\text { perawatan dan mengolah hasil } \\
\text { panen. }\end{array}$ \\
\hline
\end{tabular}

\section{Hasil Intervensi Program (Capaian Dambaan Perubahan Perilaku)}


Dalam melakukan monitoring pada program pendampingan masyarakat di Sorong Selatan, Yayasan Indonesia Lebih Baik (YILB) menyusun panduan untuk melihat perubahan perilaku mitra langsung setelah dilakukan intervensi program. Acuan tersebut termuat dalam Tabel 4.

Tabel 4. Acuan Pengukuran Program

Monitoring dilakukan per Quarter (Q)

\begin{tabular}{|c|c|c|c|c|c|}
\hline Kategori & $\begin{array}{c}\text { Frekuensi (Tidak } \\
\text { Pernah/Jarang/Sering/Sanga } \\
\text { t Sering) * }\end{array}$ & $\underset{* *}{\text { Aktor }}(\%)$ & $\begin{array}{c}\text { Produk } \\
\text { (ada/tidak) } \\
* * *\end{array}$ & \multicolumn{2}{|c|}{ Hipotetik standard (1 Quarter) } \\
\hline $\begin{array}{l}\text { Tidak } \\
\text { berubah }\end{array}$ & Tidak Pernah & o & Tidak ada & Tidak Pernah & o dalam go hari \\
\hline $\begin{array}{l}\text { Cukup } \\
\text { berubah }\end{array}$ & Jarang & $10-50$ & Ada & Jarang & 1-15 kali dalam 9o hari \\
\hline Berubah & Sering & $60-90$ & Ada & Sering & 16-30 kali dalam go hari \\
\hline $\begin{array}{l}\text { Sangat } \\
\text { berubah }\end{array}$ & Sangat Sering & $>90$ & Ada & Sangat Sering & >30 kali dalam 9o hari \\
\hline
\end{tabular}

berubah

${ }^{*}$ Frekuensi adalah berapa sering terlihat dalam suatu waktu tertentu

** Aktor adalah presentase jumlah orang dari keseluruhan target orang yang terlihat menunjukkan perubahan

** Produk adalah bukti fisik terhadap hasil perubahan perilaku, misaknya hasil kerajinan tangan, kain, buku catatan dll

Setelah dilakukan intervensi program, berupa penguatan kapasitas ekonomi rumah tangga dan bidang pertanian, serta dilakukan pendampingan setiap harinya selama enam bulan program di tahun pertama, terdapat capaian dambaan berupa perubahan perilaku mitra langsung pada level expect to see dapat dilihat pada Tabel 5 .

Tabel 5. Hasil Perubahan Perilaku Mitra Langsung

\begin{tabular}{|c|c|c|c|c|c|c|c|}
\hline \multirow{3}{*}{$\begin{array}{l}\text { Ultimate } \\
\text { Outcome }\end{array}$} & \multirow{3}{*}{ Triwulan } & \multirow{3}{*}{ Expect to See } & \multicolumn{5}{|c|}{ Evidences } \\
\hline & & & \multirow[b]{2}{*}{$\mathrm{F}(\mathrm{n})$} & \multirow{2}{*}{$\begin{array}{c}\text { Aktor } \\
(\%)\end{array}$} & \multicolumn{2}{|r|}{ Produk } & \multirow[b]{2}{*}{ Kategori } \\
\hline & & & & & Ada/Tidak & $\begin{array}{c}\text { Means of } \\
\text { Verification }\end{array}$ & \\
\hline \multirow{6}{*}{$\begin{array}{l}\text { Mama-mama } \\
\text { mampu } \\
\text { mengatur } \\
\text { ekonomi rumah } \\
\text { tangga, mampu } \\
\text { mengolah } \\
\text { lahannya sendiri } \\
\text { serta } \\
\text { mengembangka } \\
\text { n produk } \\
\text { bernilai ekonomi } \\
\text { secara mandiri }\end{array}$} & I & $\begin{array}{l}\text { Mama- } \\
\text { mama }\end{array}$ & & & & & $\begin{array}{l}\text { Belum } \\
\text { berubah }\end{array}$ \\
\hline & II & $\begin{array}{l}\text { belajar } \\
\text { keterampila } \\
\text { n sehari-hari } \\
\text { (boga dan } \\
\text { kerajinan) }\end{array}$ & $\begin{array}{l}\text { Sangat } \\
\text { sering } \\
(24 \mathrm{x}, \\
100 \%)\end{array}$ & 80 & Ada & $\begin{array}{l}\text { Dokumentasi/foto } \\
\text {, produk kerajinan } \\
\text { tangan berupa } \\
\text { kain rumput dan } \\
\text { kue hasil olahan } \\
\text { dari sagu }\end{array}$ & Berubah \\
\hline & I & $\begin{array}{l}\text { Mama- } \\
\text { mama } \\
\text { mampu }\end{array}$ & & & & & $\begin{array}{l}\text { Belum } \\
\text { berubah }\end{array}$ \\
\hline & II & $\begin{array}{l}\text { mengelola } \\
\text { hasil } \\
\text { budidaya } \\
\text { kebun }\end{array}$ & $\begin{array}{l}\text { Sangat } \\
\text { sering } \\
(24, \\
100 \%)\end{array}$ & 40 & & $\begin{array}{l}\text { Dokumentasi/foto } \\
\text {, hasil sayur } \\
\text { berkebun }\end{array}$ & Berubah \\
\hline & I & $\begin{array}{l}\text { Mama- } \\
\text { mama }\end{array}$ & $\begin{array}{l}\text { Tidak } \\
\text { perna }\end{array}$ & & & & $\begin{array}{l}\text { Belum } \\
\text { berubah }\end{array}$ \\
\hline & II & $\begin{array}{l}\text { Memahami } \\
\text { prioritas } \\
\text { kebutuhan } \\
\text { dalam } \\
\text { keluarga }\end{array}$ & $\begin{array}{l}\text { h } \\
\text { Sering } \\
(9 \mathrm{x}, \\
75 \%)\end{array}$ & 50 & Ada & $\begin{array}{l}\text { Dokumentasi/foto } \\
\text {, catatan } \\
\text { pendapatan dan } \\
\text { pengeluaran }\end{array}$ & $\begin{array}{l}\text { Cukup } \\
\text { berubah }\end{array}$ \\
\hline
\end{tabular}

Hasil pada tabel 5 dapat digambarkan bahwa pada enam bulan pertama proses pendampingan terhadap masyarakat di kampung Kais-Tapuri pada capaian dambaan mama-mama belajar keterampilan sehari-hari (boga dan kerajinan) di triwulan pertama belum menunjukan ada perubahan, dikarenakan adanya fokus program regenerasi pada pemuda untuk melestarikan 


\section{JPPM (Jurnal Pendidikan dan Pemberdayaan Masyarakat), 7 (2), 2020 - 112}

Sanuri Sanuri

kerajinan tangan, sehingga belum menyentuh aspek pemberdayaan pada mama-mama. Namun, pada triwulan kedua intensitas yang terjadi sangat sering, dengan intensitas 24 kali frekuensi terlihat melakukan aktivitas belajar keterampilan sehari-hari berupa boga dan kerajinan tangan selama kurun waktu tiga bulan, dengan aktor yang berubah sebanyak 16 aktor dari total 20 aktor atau sebesar sebesar $80 \%$, sehingga dapat dikategorikan bahwa terdapat perubahan yang positif terhadap mitra langsung setelah dilakukan pendampingan berupa penanaman kapasitas dalam bentuk pelatihan dan pendampingan dalam proses pembuatan kerajinan tangan.

Hasil pada tabel 5 dapat digambarkan bahwa pada enam bulan pertama proses pendampingan terhadap masyarakat di kampung Kais-Tapuri pada capaian dambaan mama-mama mampu mengelola hasil budidaya kebun di triwulan pertama belum menunjukan ada perubahan, dikarenakan pada triwulan pertama mama-mama baru mulai diberikan pemahaman terkait berkebun, selanjutnya melakukan proses berkebun dengan kelompok tani masing-masing (dengan langkah awal pembersihan lahan, pembuatan bedeng, penyemaian, penanaman dan pembuatan pupuk organik serta perawan secara bersama). Namun, pada triwulan kedua intensitas yang terjadi sangat sering, dengan intensitas 24 kali frekuensi terlihat melakukan aktivitas berkebun dan mampu mengelola hasil budidaya kebun selama kurun waktu tiga bulan, dengan aktor yang berubah sebanyak 8 aktor dari total 20 aktor atau sebesar sebesar $40 \%$, aktor yang berubah masih terlihat sedikit dikarenakan banyak masyarakat yang masih mempunyai kesibukan seperti menokok sagu di hutan. Sehingga dapat dikategorikan bahwa terdapat perubahan yang positif terhadap mitra langsung setelah dilakukan pendampingan berupa penanaman kapasitas dalam bentuk pelatihan dan pendampingan dalam proses berkebun dan mengelola hasil budidaya kebun.

Hasil pada tabel 5 dapat digambarkan bahwa pada enam bulan pertama proses pendampingan terhadap masyarakat di kampung Kais-Tapuri pada capaian dambaan mama-mama memahami prioritas kebutuhan dalam keluarga di triwulan pertama belum menunjukan ada perubahan, dikarenakan masih berfokus pada pentingnya keterlibatan orangtua terhadap pendidikan anak dan pertanian organik. Selanjutnya, setelah hasil pertanian sudah dipanen, akan diarahkan terlebih dahulu untuk pemenuhan gizi di dalam keluarga, baru kemudian untuk penjualan, sambil di dalamnya diajarkan untuk mengelola keuangan rumah tangga. Namun, pada triwulan kedua intensitas yang terjadi sering, dengan intensitas 9 kali frekuensi terlihat mama-mama memahami prioritas kebutuhan dalam keluarga dan mampu mengatur keuangan rumah tangga, dengan aktor yang berubah sebanyak 10 aktor dari total 20 aktor atau sebesar sebesar 50\%. Sehingga dapat dikategorikan bahwa terdapat perubahan yang positif terhadap mitra langsung setelah dilakukan pendampingan berupa penanaman kapasitas dalam bentuk pelatihan ekonomi rumah tangga dan pendampingan dalam proses pencatatan pendapatan dan pengeluaran keluarga. Penyuluhan mengenai pengelolaan Ekonomi Rumah Tangga sudah dilakukan dimana masih diawali dengan pemberian pemahaman tentang kebutuhan vs keingian, manajemen keuangan (pencatatan pendapatan dan pengeluaran), menabung, dan usaha mandiri.

\section{Evaluasi Program}

Outcome Mapping memberi program suatu sistem yang secara terus menerus mengajak untuk berpikir secara holistik dan strategis tentang bagaimana program dapat mencapai hasil yang diharapkan. Outcome Mapping melakukan evaluasi program dengan memantau tiga aspek utama: (1) Perubahan perilaku Mitra Langsung; (2) Strategi program; dan (3) Bagaimana cara Tim Pelaksana program menjalankan fungsinya.

Dalam melakukan pendampingan masyarakat yang dilakukan dengan menggunakan pemberdayaan outcome mapping, evaluasi program sangat mungkin dilakukan setiap bulan sekali dari rencana kerja yang merupakan strategi program yang dilakukan oleh peneliti, sehingga akan memungkinkan terjadi perubahan perencanan dalam setiap bulan. Selain itu untuk evaluasi rancangan terarah, dimana melihat sejauh mana perubahan perilaku yang dicapai oleh mitra langsung dilakukan setiap tiga bulan sekali. Dalam outcome mapping, sangat memungkinkan 
untuk merubah strategi yang sudah dijalankan, jika memang belum berhasil merubah perilaku masyarakat, sehingga perlu dilakukan evaluasi setiap tiga bulan sekali. Upaya yang dilakukan pleh peneliti (pendamping masyarakat) seperti cara melakukan pendampingan dengan kreativitas yang dalam penyampaian ataupun pendekatan yang dilakukan kepada masyarakat juga tidak luput dari evaluasi program. Dengan melibatkan Tim Pelaksana (pendamping) secara aktif dalam proses monitoring dan evaluasi, Outcome Mapping memberdayakan mereka agar dapat menyatakan secara jelas, dengan data yang akurat dan dapat diandalkan, apa yang telah mereka lakukan untuk mendukung hasil program dan tingkat perubahan yang terjadi pada mitra langsung.

\section{SIMPULAN}

Hasil penerapan model pemberdayaan outcome mapping pada perempuan usia produktif dalam upaya meningkatkan ekonomi kreatif berbasis kearifan lokal masyarakat adalaah sebagai berikut: (1) Perencanaan partisipatoris terdiri dari identifikasi kebutuhan terkait ekonomi rumah tangga bersama dengan kepala kampung, aparat kampung, perwakilan perempuan di dua kampung (2) Penentuan mitra langsung dan stakeholder potensial, mitra langsung yang terpilih terdiri dari 20 perempuan usia produktif dari dua kampung, dan stakeholder potensial terdiri dari kepala kampung, pendeta, kepala suku, dan kader posyandu (3) Merancang program (desain program) yaitu berupa rancangan terarah yang teridri dari: visi dan misi (ultimate goal), mitra langsung, penanda kemajuan, peta strategi program (4) Menentukan rencana kerja (workplan) berupa pelatihan dan pendampingan, yang dimulai dengan membentuk kelompok tani, pelatihan terkait ekonomi rumah tangga dan pendampingan (5) Indikator keberhasilan pelatihan adalah adanya perubahan perilaku perempuan usia produktif yang dapat dilihat pada penanda kemajuan yang sudah dibuat selama semester pertama

Saran yang dapat diberikan dengan adanya pemberdayaan ekonomi kreatif berbasis kearifan lokal dengan menggunakan pendekatan outcome mapping adalah: (1) pendekatan outcome mapping harus dilakukan dengan pendampingan secara intensif, yaitu tinggal bersama masyarakat dalam kurun waktu sekitar 1 bulan, (2) perubahan perilaku mitra langsung tidak hanya dilihat pada saat proses pelatihan, tetapi juga dilihat dari keseharian mitra langsung setelah dilakukan pelatihan, (3) pendekatan outcome mapping membutuhkan waktu yang lama, karena melihat perubahan perilaku yang terjadi pada mitra langsung

\section{DAFTAR PUSTAKA}

Azizah, S. N., \& Muhfiatun, M. (2018). Pengembangan ekonomi kreatif berbasis kearifan lokal pandanus handicraft dalam menghadapi pasar modern perspektif ekonomi syariah (Study Case di Pandanus Nusa Sambisari Yogyakarta). Aplikasia: Jurnal Aplikasi Ilmu-ilmu Agama, 17(2), 63-78.

Badan Pusat Statistik. (2017). Persentase penduduk miskin Maret 2017 mencapai 10,64 persen. Diunduh dari www.bps.go.id, pada 13 november 2018, pukul 07.39

Deprez, S., Ongevalle, J. V., Huyse, H., \& Ambrose, K. (2010). Learning the way forward: Adapting Stzeep's planning, monitoring and evaluation process through Outcome Mapping.

Duflo, E. (2012). Women empowerment and economic development. Journal of Economic literature, 50(4), 1051-79.

Gholipour, A., Rahimian, A., Mirzamani, A., \& Zehtabi, M. (2010). IMPACT model of women's empowerment. International Business Research, 3(1), 57.

Irawan, A. (2015). Ekonomi kreatif sebagai suatu solusi mensejahterakan masyarakat dalam meningkatkan tingkat perekonomian. Proceedings SNEB.

Kamil, M., \& Riduwan. (2009). Pendidikan nonformal: pengembangan melalui pusat kegiatan belajar mengajar (PKBM) di Indonesia: sebuah pembelajaran dari kominkan di Jepang. Alfabeta. 
JPPM (Jurnal Pendidikan dan Pemberdayaan Masyarakat), 7 (2), 2020 - 114

Sanuri Sanuri

Khan, S. (2016). Women's empowerment through poverty alleviation: a socio-cultural and politico-economic assessment of conditions in Pakistan. In European Virtual Conference on Management Sciences and Economics, 1(1).

Kompas.com (2017). Agustus 2017, jumlah pengangguran naik menjadi 7,04 juta orang. Diunduh dari ekonomi.kompas.com, pada 13 november 2018, pukul 07.36

Miradj, S., \& Sumarno, S. (2014). Pemberdayaan masyarakat miskin, melalui proses pendidikan nonformal, upaya meningkatkan kesejahteraan sosial di Kabupaten Halmahera Barat. JPPM (Jurnal Pendidikan dan Pemberdayaan Masyarakat), 1(1), 101-112.

Nwobi, A. U. Non-formal education as an instrument for empowering women in Enugu State, Nigeria. International Journal of Research in Arts and Social Sciences Vol.5

Rakib, M. (2017). Strategi pengembangan ekonomi kreatif berbasis kearifan lokal sebagai penunjang daya tarik wisata. Jurnal Kepariwisataan, 1(2), 54-69.

Republik Indonesia. (2013). Peraturan Menteri Pendidikan indonesia Nomor 81 Tahun 2013

Smutylo, T. (2005). Outcome mapping: A method for tracking behavioural changes in development programs. The Institutional Learning and Change (ILAC)

Syamsi, I. (2010). Pendidikan luar sekolah sebagai pemberdaya dalam masyarakat. Diklus, 14(1). 